\title{
The relationship between intellectual styles, intelligence and learning strategies
}

\author{
A relação entre estilos intelectuais, inteligência \\ e estratégias de aprendizagem
}

\author{
Angélica Polvani TRASSI ${ }^{1}$ iD 0000-0001-6257-3857 \\ Katya Luciane de OLIVEIRA2 ID) 0000-0002-2030-500X \\ Acácia Aparecida Angeli dos SANTOS ${ }^{3}$ iD) 0000-0002-8599-7465
}

\begin{abstract}
Intellectual styles comprise a preference of people to use their cognitive abilities to solve problems. In this sense, the objective of this study was to investigate the relationship between thinking styles, verbal reasoning, and learning strategies in basic education. A total of 470 students from the $2^{\text {nd }}$ to the $9^{\text {th }}$ gradein a city in the state of Paraná participated in the study. We used the Thinking Styles Inventory - Revised II, the Learning Strategies Assessment Scale, and the Wechsler Abbreviated Scale of Intelligence. The Wechsler Scale was administered individually and to a restricted sample of 45 students. Positive relations were obtained between the intellectual styles inventory score and the learning strategies. The data pointed towards the need for further national studies to assess these correlations due to the early stage of these studies within the Brazilian population.
\end{abstract}

Keywords: Basic education; Cognitive psychology; Intelligence; Learning.

\section{Resumo}

Os estilos intelectuais compreendem a preferência das pessoas para usar suas habilidades cognitivas a fim de resolver problemas. Assim, o objetivo deste trabalho é investigar a relação entre os estilos intelectuais, a inteligência verbal e

$\checkmark \nabla \mathbf{v}$

1 Universidade Estadual de Londrina, Centro de Educação, Comunicação e Artes, Departamento de Educação. Rodovia Celso Garcia Cid (PR 445), km 380, 86051-990, Londrina, PR, Brasil. Correspondence to: E-mail: <angelica.polvani@hotmail.com>.

2 Universidade Estadual de Londrina, Centro de Ciências Biológicas, Departamento de Psicologia e Psicanálise. Londrina, PR, Brasil.

3 Universidade São Francisco, Faculdade de Psicologia. Campinas, SP, Brasil.

Support: This study was financed with resources by the Conselho Nacional de Desenvolvimento Científico e Tecnológico.

Article based on the dissertation of A.P. TRASSI, entitled "Estilos intelectuais, raciocínio verbal, estratégias de aprendizagem e compreensão verbal". Universidade Estadual de Londrina, 2016.

How to cite this article

Trassi, A. P., Oliveira, K. L., \& Santos, A. A. A. (2020). The relationship between intellectual styles, intelligence and learning strategies. Estudos de Psicologia (Campinas), 37, e170046. http://dx.doi.org/10.1590/1982-0275202037e170046 
as estratégias de aprendizagem no ensino fundamental. Participaram da pesquisa 470 alunos do segundo ao nono ano do ensino fundamental de uma cidade do Paraná. Foram utilizados o Inventário de Estilos Intelectuais - Revisado II, a Escala de Avaliação das Estratégias de Aprendizagem e a Escala Wechsler de Inteligência Abreviada. A aplicação foi realizada de forma individual para a Escala Wechsler, em uma amostra restrita a 45 alunos. Foram obtidas relações positivas entre o escore do inventário de estilos intelectuais e as estratégias de aprendizagem. Os dados apontaram a necessidade de mais estudos nacionais a fim de avaliar e confirmar essas correlações, haja vista que os trabalhos com a população brasileira são incipientes.

Palavras-chave: Ensino fundamental; Psicologia cognitiva; Inteligência; Aprendizagem.

Learning is a process that modifies the Central Nervous System based on the life experiences of a person, allowing the best adaptation of individuals to their environment (Rotta, Ohlweiler, \& Risgo, 2016). Some cognitive processes, such as attention, thought flexibility, and executive functions are involved in learning, since they are related to reading, writing, and math skills (Cypel, 2006; Simão, Lima, Natalin, \& Ciasca, 2010). Therefore, intelligence is a way to predict learning and school performance (Martins, Alves, \& Almeida, 2015).

According to Martins et al. (2017), there are several explanatory models for intelligence, which differ from cognitive performance and human development. According to Sternberg (2010), intelligence is the ability to learn from experience, using metacognitive strategies to develop ways of adapting to the environment, planning, monitoring, and evaluating problem solving. The Information Processing Theory, which in general studies how information is processed, is the framework for understanding intelligence in this study (Bzuneck, 2004; Sternberg, 2010).

According to the Information Processing Theory, speed and accuracy to process information, as well as working memory skills and complex problem solving, are part of intelligence. Verbal intelligence, the specific focus of this research, is used to solve problems in situations involving: information processing, oral comprehension, verbal expression, concept formation, word knowledge, abstract reasoning and the ability to acquire, retain and recover information. These skills can predict students' school performance (Gomes \& Golino, 2012; Sternberg, 2010; Valentini \& Laros, 2014).

Oliveira, Santos, and Scacchetti (2016) emphasize that students have different learning patterns, which vary according to the type of task (reading, text comprehension, among others). Thus, in addition to cognitive skills, each person has specific skills that influence the way they acquire and process information. Research in the field of intellectual styles investigates the peculiar way in which individuals process information and how it affects learning.

Thus, intellectual styles are understood as the person's predilection for using their abilities and reasoning to solve problems, process information, and perform tasks (Zhang, Sternberg, \& Fan, 2013; Zhang, 2015). These styles were studied from the perspective of Sternberg's Theory of Mental Self-Government, which associated thinking styles to the ways of governing a society. In 2005, Zhang and Sternberg (2005) classified three types of intellectual styles: Type I, II and III. The first type involves the legislative, judicial, liberal, global, and hierarchical styles, and it refers to a preference for activities with a higher level of cognitive complexity, creativity, and independence when performing a task. Type II consists of the executive, conservative, local, and monarchic styles, indicating, therefore, a predilection for following rules and activities that denote a lower level of mental complexity. Type III, in turn, involves the oligarchic, anarchic, internal, and external styles and it includes characteristics of the type I or II, depending on the type of task demanded and personal interests (Nielsen, 2014; Zhang et al., 2013; Xie, Gao, \& King, 2013).

A priori, there is no direct relationship between intellectual styles and level of intelligence, but certain styles may have a correlation with intellectual abilities, since their purpose is to understand how people use 2 their cognitive ability (Sternberg, 1990; Sternberg, Castejón, \& Bermejo, 1999; González-Pienda et al., 2004). 
However, intellectual styles are correlated with academic performance, but data are not consistent about which styles contribute to school success (Gomes, Marques, \& Golino, 2014; Xie et al., 2013).

In addition to intellectual styles, learning strategies are also fundamental for school performance, since they help the learning process and accomplishment of a task (Galvão, Câmara, \& Jordão, 2012; Zumbrunn \& Bruning, 2013). According to Dembo (1994), there are two types of learning strategies: cognitive and metacognitive. Cognitive strategies allow students to learn, remember, and understand certain subjects, favoring effective storage of information. They are divided into: rehearsal (recitation of a list and copying a text literally); preparation (paraphrasing, taking notes, creating analogies, answering questions), and organization (selecting main ideas, concept maps, schemas).

According to Corso, Sperb, Jou, and Salles (2013), the learning process requires planning and regulation skills of the activity based on specific objectives. Based on this, metacognition is understood as the students' awareness of their learning process (Marini \& Boruchovitch, 2014).

Therefore, metacognitive strategies are resources that allow the individual to plan, monitor and regulate thinking and behavior. They are divided into metacognitive strategies for planning, monitoring, and regulation. While planning strategies occur when students establish their study objectives, monitoring strategies take place when students supervise their understanding of a certain subject. Last, learning regulation strategies are present when individuals verify their performance by analyzing if their study strategies are effective (Dembo, 1994).

Thus, students must be aware of their learning process, identify study strategies, goals and their objectives to achieve meaningful learning (Alcará \& Santos, 2013; Cunha \& Boruchovitch, 2012; Teixeira \& Alliprandini, 2013). Good learners use diversified and efficient learning strategies to access stored knowledge. In addition, they have adequate metacognitive abilities and monitor their learning process (Dembo, 2000; Grillo, 2003). Recent studies have found that students with improved school performance are able to select and use more learning strategies, they have more studying habits, monitor their learning and academic performance, organize and manage their study time, self-evaluate their learning strategies, and have more skills to overcome obstacles and difficulties (Frison, 2016; Prates, Lima, \& Ciasca, 2016; Veiga Simão \& Frison, 2013; Zumbrunn \& Bruning, 2013).

It was found that several cognitive abilities are essential for school success, since they enable the student to perform satisfactory information processing, as well as efficient retrieval of their knowledge. However, these strategies are not sufficient for improved learning. To achieve this, the student must have more favorable strategies to solve problems and study. Thus, our hypothesis is that there may be a relation between intellectual styles, learning strategies, and intelligence of Brazilian schoolchildren.

In Brazil, only the study of Inácio (2016) sought to investigate and compare intellectual styles, memory performance, and learning strategies of students from the $2^{\text {nd }}$ to the $9^{\text {th }}$ grade in the state of Paraná $(n=370)$. Therefore, it is noteworthy that there are almost no studies on intellectual styles in Brazil. The different types of samples, demographic variables (school year, gender, age), and variables that measure school performance have not been investigated yet. It is important to remember that intellectual styles are a recently introduced scientific construct in Brazil.

In view of the above-mentioned, the main objective of this exploratory study was to investigate the relation between intellectual styles, verbal intelligence, and learning strategies of students from $2^{\text {nd }}$ to $9^{\text {th }}$ grade in a city in the state of Paraná. It should be noted that we do not intend to establish a causal relationship between the variables studied, but rather address the issue using a descriptive design to draw exploratory considerations about the relations observed. 


\section{Method}

\section{Participants}

A total of 470 students from the $2^{\text {nd }}$ to $9^{\text {th }}$ grade from five public schools in a city in the north of Paraná participated in the study. Of the total, $60 \%(n=283)$ were girls and $40 \%(n=187)$ boys. The mean age of the students was 10.7 years, the youngest was 7 years old and the oldest 15 years old.

\section{Instruments}

To assess the students' intellectual styles, learning strategies, and verbal intelligence, the following instruments were used: (1) Thinking Styles Inventory - Revised II (TSI-R2) (Sternberg et al., 2007): consists of 65 items that evaluate 13 intellectual styles. For each statement, participants rate themselves on a 7-point Likert scale, with 1 indicating that the statement does not represent the way they carry out tasks and 7 suggesting that the statement characterizes extremely well the way they carry out tasks. The instrument can be applied individually or collectively. The inventory was translated, then the back translation was carried out and adapted for the Brazilian population. Four specialist judges in the field of psychological evaluation analyzed the instrument to verify the adequacy of the items. Studies on the internal factorial structure are still being carried out. Table 1 shows some sample items from the Thinking Styles Inventory - Revised II (TSI-R2); (2) Wechsler Abbreviated Scale of Intelligence (WASI) (Wechsler, 2014): aims to briefly assess general intelligence, verbal and executive intelligence using four tests: similarities, vocabulary, cubes and matrix reasoning, the first two referring to the verbal area. This instrument is administered individually to people between the ages of 6 and 89 years. To meet the objectives of this study, only verbal tests were applied and quantitatively assessed by verbal IQ. The test was approved in Brazil by the Federal Council of Psychology in 2014, but the test is reserved for the exclusive use of psychologists, and publication is prohibited. Validity studies are available in Wechsler (2014); (3) Assessment Scale of Learning Strategies for Elementary Education (EAVAP-EF) (Oliveira, Boruchovitch, \& Santos, 2010): assesses learning strategies (cognitive and metacognitive)

Table 1

Sample items of the Thinking Styles Inventory - Revised II and their styles

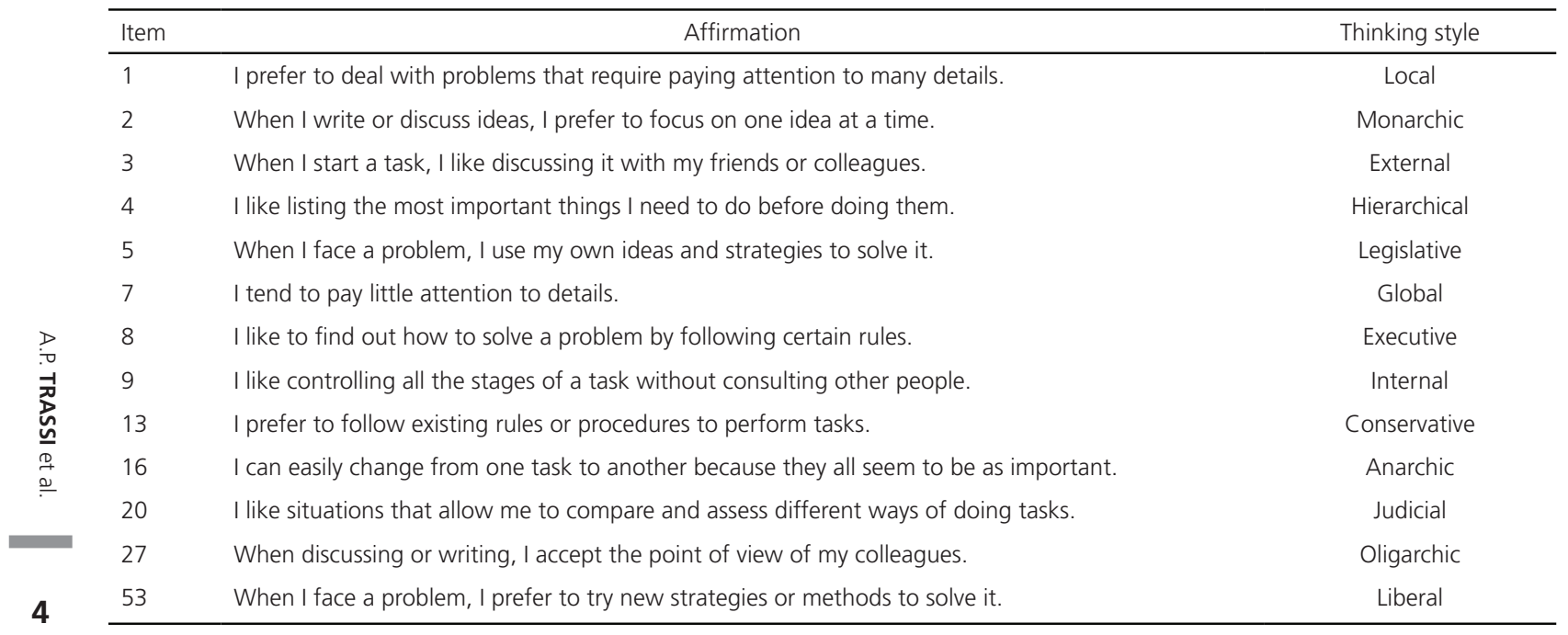


as well as the absence of dysfunctional metacognitive strategies of children aged 7-16 years in elementary school. It consists of 31 items on a three-point Likert scale (always, sometimes, never). There is no time limit to complete the instrument and it can be administered individually or collectively. This instrument was approved by the Federal Council of Psychology in 2010, and edited in Brazil by Pearson Clinical Brasil. Validity studies are available in Oliveira et al. (2010).

\section{Procedures}

The project was approved by the Ethics Committee of the university. The parents or guardians of the students signed the term of free and informed consent, authorizing research to be conducted on them. Data collection of the 470 students was carried out collectively in the classroom for the TSI-R2 and EAVAP-EF instruments, and individually for the WASI with 45 students, five from each school year, chosen randomly by the educational institution. Collection times were scheduled with schools. The data collection was organized in a spreadsheet and submitted to descriptive and inferential statistical analysis (Pearson's correlation and partial correlation tests).

\section{Results}

The Pearson's correlation test was used with the purpose of investigating the relation between intellectual styles, verbal intelligence, and learning strategies. We shall first discuss the results of the correlations obtained between the intellectual style variables assessed by TSI-R2 and the Verbal Intellectual Quotient.

As shown in Table 2, it was found that the intellectual quotient of verbal intelligence presented a statistically significant negative correlation with the conservative style scores $(r=-0.333)$, indicating that, in an exploratory way, the higher the score of Verbal IQ, the lower the score in the conservative style. It should be noted that the sample on intelligence was restricted to only 45 students. Thus, it may not have been able to represent all students in elementary school from $2^{\text {nd }}-9^{\text {th }}$ grades, which may have interfered in the

Table 2

Results of the correlation between Thinking Styles Inventory- Revised II and the Verbal Intellectual Quotient (IQ)

\begin{tabular}{lc}
\hline Subscales & Verbal IQ \\
\hline Legislative & 0.217 \\
Executive & -0.121 \\
Judicial & 0.222 \\
Global & -0.154 \\
Local & -0.142 \\
Liberal & 0.038 \\
Conservative & $-0.333^{*}$ \\
Hierarchical & 0.077 \\
Monarchic & 0.137 \\
Oligarchic & 0.204 \\
Anarchic & -0.006 \\
Internal & 0.051 \\
External & -0.032 \\
\hline
\end{tabular}

Note: *Statistically significant results at $p \leq 0.050$. 
result. Further research with more significant population samples are required to obtain results that can be generalized for this variable.

The study also sought to establish a relation between the variables of intellectual styles and learning strategies. To do so, two analyses were conducted: a simple correlation $(r)$ analysis, but also considering that simple correlations are indicators of covariance between two variables, without controlling external variables; and the partial correlation analysis ( $r$ partial). The purpose of this study was to control the effects of the other intellectual styles on each of the styles analyzed and their relationship with the learning strategy variables. Table 3 shows the data from the coefficients of the simple correlation, as well as the data of the partial correlation between each style and the subscales of learning strategies.

Table 3 shows that simple correlation leads to an overestimation of the correlations between the intellectual styles and learning strategies. However, during analysis, controlling the external variables by means of the partial $r$ (in this case it balances the interference of the other styles in the pair of relation between a certain style and the strategies), it was found that the correlations, although for the most part have declined in magnitude, indicated some degree of correlation. Although most of the coefficients were low or almost null, the coefficients of low magnitude or almost null still represented $4 \%$ of the explained variance.

According to Table 3, the results from the partial correlation analysis indicated that, in the absence of Dysfunctional Metacognitive Strategies, statistically significant and positive correlations were obtained, although of low magnitude or almost null, for the legislative $(r=0.109)$, executive $(r=0.121)$, judicial $(r=0.181)$ and hierarchical styles $(r=0.144)$.

As for the Cognitive Strategy subscale, statistically significant and positive correlations were found for the following styles: executive $(r=0.100)$, local $(r=0.149)$, conservative $(r=0.183)$, hierarchical $(r=0.235)$, monarchic $(r=0.118)$ and anarchic $(r=0.109)$, and a statistically significant but negative correlation for the liberal style $(r=-0.122)$. It should be noted that the data refer to the partial correlation analysis.

Table 3

Results of simple correlation ( $r$ ) and partial correlation (r partial) between Thinking Styles Inventory - Revised II and the Assessment Scale of Learning Strategies

\begin{tabular}{|c|c|c|c|c|c|c|c|c|}
\hline \multirow[t]{2}{*}{ Subscales } & \multicolumn{2}{|c|}{$\begin{array}{l}\text { Absence of dysfunctional } \\
\text { metacognitive strategies }\end{array}$} & \multicolumn{2}{|c|}{ Cognitive strategies } & \multicolumn{2}{|c|}{ Metacognitive strategies } & \multicolumn{2}{|c|}{ General score } \\
\hline & $r$ & $r$ partial & $r$ & $r$ partial & $r$ & $r$ partial & $r$ & r partial \\
\hline Legislative & $0.131^{*}$ & $0.109^{*}$ & $0.242^{*}$ & 0.036 & $0.142^{*}$ & $0.124^{*}$ & $0.254^{*}$ & 0.063 \\
\hline Executive & $0.298^{* *}$ & $0.121^{*}$ & $0.279^{*}$ & $0.100^{*}$ & 0.022 & -0.074 & $0.347^{* *}$ & $0.163^{*}$ \\
\hline Judicial & $0.311^{* *}$ & $0.181^{*}$ & $0.344^{* *}$ & 0.073 & $0.133^{*}$ & $0.109^{*}$ & $0.419^{* *}$ & $0.198^{*}$ \\
\hline Global & $0.170^{*}$ & 0.029 & $0.188^{*}$ & 0.030 & 0.080 & 0.045 & $0.238^{*}$ & $0.151^{*}$ \\
\hline Local & $0.248^{*}$ & 0.028 & $0.343^{* *}$ & $0.149^{*}$ & 0.077 & 0.049 & $0.369^{* *}$ & $0.115^{*}$ \\
\hline Liberal & $0.193^{*}$ & 0.040 & $0.243^{*}$ & $-0.122^{*}$ & 0.027 & -0.080 & $0.261^{*}$ & -0.037 \\
\hline Conservative & $0.198^{*}$ & -0.036 & $0.229^{*}$ & $0.183^{*}$ & 0.039 & 0.011 & $0.258^{*}$ & $0.157^{*}$ \\
\hline Hierarchical & $0.333^{* *}$ & $0.144^{*}$ & $0.404^{* *}$ & $0.235^{* *}$ & 0.031 & 0.013 & $0.432^{* *}$ & $0.218^{*}$ \\
\hline Oligarchic & 0.071 & 0.016 & $0.194^{*}$ & 0.058 & 0.093 & 0.062 & $0.187^{*}$ & 0.078 \\
\hline Anarchic & $0.169^{*}$ & 0.053 & $0.200^{*}$ & $0.109^{*}$ & -0.017 & -0.095 & $0.203^{*}$ & -0.127 \\
\hline Internal & $0.209^{*}$ & 0.044 & $0.226^{*}$ & 0.112 & -0.019 & 0.007 & $0.241^{*}$ & -0.055 \\
\hline External & 0.100 & -0.073 & $0.165^{*}$ & 0.080 & 0.088 & 0.045 & $0.179^{*}$ & 0.051 \\
\hline
\end{tabular}


In the analysis of partial correlations, statistically significant and positive relationships were found for the Metacognitive Strategy subscale for the legislative $(r=0.124)$ and judicial styles $(r=0.109)$, although of low magnitude or almost null. Finally, the following correlations for the General Score were found: executive ( $r=0.163)$, judicial $(r=0.198)$, global $(r=0.151)$, local $(r=0.115)$, conservative $(r=0.157)$, hierarchical $(r=0.218)$ and monarchic styles $(r=0.111)$. The study also investigated the relationship between verbal intelligence and learning strategies. The results are shown in Table 4.

Table 4 shows that a statistically significant and positive correlation was found between the verbal IQ and the Metacognitive Strategy subscale $(r=0.347)$, suggesting that the students' higher score in verbal intelligence (and greater ability to solve verbal problems) leads to a more metacognitive tendency. According to literature on the subject, we shall discuss these results.

Table 4

Results of the correlation between Verbal Intellectual Quotient (IQ) and the Assessment Scale of Learning Strategies

\begin{tabular}{lc}
\hline & Verbal IQ \\
\hline Absence of dysfunctional metacognitive strategies & 0.063 \\
Cognitive strategies & 0.025 \\
Metacognitive strategies & $0.347^{*}$ \\
General score & 0.130 \\
\hline
\end{tabular}

Note: *Statistically significant results at $p \leq 0.050$.

\section{Discussion}

First it should be noted that the relations found in the present study are exploratory in nature and they do not intended to establish causal relationships. Thus, from the data obtained with this research, we found that the intellectual quotient of verbal intelligence was statistically significant, but negatively correlated with the conservative style. Thus, it may be suggested that people with a higher verbal ability have a lower tendency to deal with known problems that involve rule-following and ready-made ways of doing things (Sternberg, 1990; Zhang \& Sternberg, 2005). This result, in turn, contradicts the findings of Sternberg (1990), Grigorenko and Sternberg (1997), and Sternberg et al. (1999), since the researchers did not find a relationship between the person's thinking styles and their cognitive ability.

One of the possible explanations is because these results are due to the idiosyncrasies of the sample in our study. Other possible explanations include the use of different intelligence assessment tools as well as other cultural characteristics that imply different results. It must be noted that the sample for verbal intelligence in the present research was small, which can lead to restrictions in the interpretation of the results. Therefore, further studies with the purpose of investigating these relations in an exploratory way and using more representative samples of verbal intelligence are required to verify if these results can be confirmed.

However, Inácio, Oliveira, and Santos (2018) found a relationship between visual perception ability with styles of type I and II, but the correlations were statistically negative in the latter. Statistically negative relations between visual memory ability and the conservative style were also observed. These data corroborate the point of view of Sternberg (1990) that specific styles could have an affinity with certain cognitive abilities.

A simple correlation was found between TSI-R2 and EAVAP-EF. However, as simple correlations do not control for external variables, by controlling the effects, as represented by the partial $r$, shown 
in Table 3, the value of several coefficients decreased in relation to the simple correlation, becoming almost null.

A relationship between TSI-R2 and EAVAP-EF was identified. We found higher correlations between the General Score and Cognitive Strategy subscales with the hierarchical style and between the absence of dysfunctional metacognitive strategy subscale and the judicial style, whereas low correlations were found for the Metacognitive Strategies with the legislative and judicial styles.

Therefore, in general, except for the Metacognitive Strategies, there is an exploratory and non-causal tendency for learning strategies to be correlated with intellectual styles of type I. Thus, it may be inferred that more creative students who enjoy activities that involve a greater level of thinking flexibility and problem solving are inclined to use a greater number of learning strategies. These data corroborate the findings of Dembo (2000), Teixeira and Alliprandini (2013), Cunha and Boruchovitch (2012), according to whom the most effective students are those who can use a wide variety of studying strategies to adapt to different school situations.

However, Inácio (2016) found slightly different results regarding the correlation between the subscales in EAVAP-EF and TSI-R2. For the subscale Absence of Dysfunctional Metacognitive Strategies, correlations with the legislative $(r=0.230)$, executive $(r=0.349)$, conservative $(r=0.369)$, monarchic $(r=0.300)$ and internal $(r=0.303)$ styles were found; however, in the present study, relations with the legislative, executive, judicial and hierarchical styles were found.

For the Cognitive Strategy subscale, Inácio (2016) found the following correlations: executive $(r=0.278)$, judicial $(r=0.404)$, global $(r=0.376)$, local $(r=0.363)$, liberal $(0.311)$, hierarchical $(r=0.482)$, and anarchic $(r=0.273)$ styles. In the present study, correlations with the executive, local, liberal, conservative (negative correlation), hierarchical, monarchic and anarchic styles were observed. As for the Metacognitive Strategy subscale, the author found the following relations: judicial $(r=0.302)$, global $(r=0.200)$ and liberal $(r=0.221)$ styles. In the present study, correlations were found for the legislative and judicial styles only.

Finally, Inácio (2016) found the following correlations for the General Score: legislative $(r=0.261)$, executive $(r=0.435)$, judicial $(r=0.379)$, global $(r=0.210)$, local $(r=0.352)$, liberal $(r=0.284)$, conservative $(r=0.304)$, hierarchical $(r=0.419)$, monarchic $(r=0.282)$, anarchic $(r=0.259)$ and internal $(r=0.255)$ styles. However, in the present study, correlations were obtained between the executive, judicial, global, local, conservative, hierarchical and monarchic styles.

Although Inácio (2016) found correlations between types I and II and the subscales of EAVAP-EF, these correlations were different from those found in this present study. Thus, despite the fact that the samples from the two studies were from the state of Paraná and the same instruments were used, there were differences in the results. This divergence may be because the author administered the instruments individually, while in this study we administered them collectively. It should be noted, however, that to date, except for Inácio's study (2016), no Brazilian studies were conducted to study the association between intellectual styles and learning strategies in a more detailed way in a Brazilian sample.

Finally, as shown in Table 4, a correlation between the verbal intelligence score and Metacognitive Strategy score was found, showing that, in an exploratory way, without the intention of establishing a causal relationship, the higher the students' ability to solve verbal problems, the more awareness, monitoring, and self-evaluation they will have of their cognitive and learning process (Frison, 2016). Research (Grillo, 2003; Pascualon-Araujo \& Schelini, 2013; Zampieri \& Schelini, 2013) shows that metacognitive skills are accompanied by good cognitive performance, and students who monitor their learning better show improved information processing and school performance, since they devise more effective strategies to acquire, organize, and recover knowledge. Thus, metacognitive skills tend to contribute to the students' successful storage of school 8 content and knowledge acquired in their daily lives. 
Studies conducted by Oliveira (2008) and Joly and Dias (2012) found similar results in their research, since they found correlations between verbal IQ, measured by WISC-III and studying strategies, particularly metacognitive strategies, confirming that this type of strategy is related to verbal intelligence.

In view of this research, intellectual styles, verbal intelligence, and learning strategies can contribute to learning as they relate to more efficient information processing, as well as identifying the preferred ways students use their skills, and consequently obtain knowledge. Knowing how each student learns, studies, and solves problems, favors their participation in the school process. Thus, the aim of this study was to help professionals in the field of education understand that each student has specific ways of learning, which may lead to the development of different teaching methods to improve students' school performance.

However, there are few Brazilian studies designed to investigate the intellectual styles in this population, which makes it difficult to compare data considering that the studies have only been developed in the North America. Further studies need to investigate whether the teachers' teaching styles influence intellectual styles and learning strategies.

Thus, further studies in Brazil should be developed to study the validity of the Thinking Styles Inventory, seek to identify the intellectual styles of Brazilian students, establish differences among the grades, and possible relations with other psychoeducational variables. One limitation of this study was the reduced number of participants when investigating the intelligence construct, so it would be important to increase the number of participants for this variable to obtain more reliable results. In addition, validity studies for the thinking styles inventory must be carried out so that it can become a research tool on the students' learning process.

\section{Contributors}

A.P. TRASSI has contributed with the research for the article. K.L. OLIVEIRA has collaborated with the orientation and coordination. A.A.A. SANTOS has aided with data analysis and general review of the study.

\section{References}

Alcará, A. R., \& Santos, A. A. A. (2013). Compreensão de leitura, estratégias de aprendizagem e motivação em universitários. Psico, 44 (3), 411-420. Recuperado de http://revistaseletronicas.pucrs.br/ojs/index.php/revistapsico/ article/view/12258/0

Bzuneck, J. A. (2004). Aprendizagem por processamento da informação: uma visão construtivista. In E. Boruchovitch \& J. A. Bzuneck (Eds.), Aprendizagem: processos psicológicos e o contexto social na escola (pp. 17-54). Rio de Janeiro: Vozes.

Corso, H. V., Sperb, T. M., Jou, G. I., \& Salles, J. F. (2013). Metacognição e funções executivas: relações entre os conceitos e implicações para a aprendizagem. Psicologia: Teoria e Pesquisa, 29(1), 21-29. Recuperado de http://www.scielo.br/ $\mathrm{pdf} / \mathrm{ptp} / \mathrm{v} 29 \mathrm{n} 1 / 04 . \mathrm{pdf}$

Cunha, N. B., \& Boruchovitch, E. (2012). Estratégias de aprendizagem e motivação para aprender na formação de professores. Interamerican Journal of Psychology, 46(2), 247-254. Recuperado de http://www.redalyc.org/articulo. oa? id $=28425280008$

Cypel, S. (2006). O papel das funções executivas nos transtornos da aprendizagem. In N. T. Rotta, L. Ohlweiler, \& R. S. Riesgo (Eds.), Transtornos da aprendizagem: abordagem neurobiológica e multidisciplinar (pp.375-390). Porto Alegre: Artmed.

Dembo, M. H.(1994). Applying educational psychology. New York: Longman.

Dembo, M. (2000). Motivation and learning strategies for college success: a self-management approach. Mahwah: Lawrence Erlbaum Associates Publishers.

Frison, L. M. B. (2016). Autorregulação da aprendizagem: abordagens e desafios para as práticas de ensino em contextos educativos. Revista de Educação PUC-Campinas, 21(1), 1-17. Recuperado de http://periodicos.puc-campinas.edu.br/ seer/index.php/reveducacao/article/view/2992 
Galvão, A., Câmara, J., \& Jordão, M. (2012). Estratégias de aprendizagem: reflexões sobre universitários. Revista Brasileira de Estudos Pedagógicos, 93(235), 627-644. Recuperado de http://www.scielo.br/pdf/rbeped/v93n235/06.pdf

Gomes, C. M. A., \& Golino, H. F. (2012). O que a inteligência prediz: diferenças individuais ou diferenças no desenvolvimento acadêmico? Psicologia: Teoria e Prática, 14(1), 126-139. Recuperado de http://pepsic.bvsalud.org/pdf/ptp/v14n1/ v14n1a10.pdf

Gomes, C. M. A., Marques, E. L. L., \& Golino, H. (2014). Validade incremental dos estilos legislativo, executivo e judiciário em relação ao rendimento escolar. Revista Eletrônica de Psicologia, Educação e Saúde, 3(2), 31-46. Recuperado de http://pepsic.bvsalud.org/pdf/ptp/v14n1/v14n1a10.pdf

González-Pienda, J. A., Núñez, J. C., González-Pumariega, S., Álvarez, L., Roces, C., Sales, P. S. (2004). Estilos de pensamiento: Análisis de su validez estructural através de lãs respuestas de adolescentes al Thinking Styles Inventory. Psicothema, 16(1), 139-148. Recuperado de http://www.psicothema.com/psicothema.asp?id=1173

Grillo, M. (2003). Construção da avaliação: estratégias metacognitivas. In C. M. G. Turra, D. Euricone, E. T. Faria, I. R. V. Hernandez, M. Grillo, \& M. A. Almeida (Eds.), Avaliação: uma discussão em aberto (pp.73-82). Porto Alegre: Edipucrs.

Grigorenko, E., \& Sternberg, R. J. (1997). Styles of thinking, abilities, and academic achievement. Exceptional Children, 63, 295-312. Retrieved from http://www.sagepub.com.ez78.periodicos.capes.gov.br

Inácio, F. F. (2016). Memória, estilos intelectuais, estratégias de aprendizagem: estudando os transtornos do neurodesenvolvimento em alunos do ensino fundamental e percepção de seus professores (Dissertação de mestrado não-publicado). Universidade Estadual de Londrina. Recuperado de http://www.uel.br/pos/mestredu/images/stories/ downloads/dissertacoes/2016/2016_-_INACIO_Francislaine_Flamia.pdf

Inácio, F. F., Oliveira, K. L., \& Santos, A. A. A. (2018). Memory and intellectual styles: Performance of students with learning disabilities. Estudos de Psicologia (Campinas), 35(1), 65-75. http://dx.doi.org/10.1590/1982-02752018000100007

Joly, M. C. R., \& Dias, A. S. (2012). Metacompreensão e inteligência: um estudo correlacional com estudantes do ensino fundamental. Estudos de Psicologia (Natal), 17(1), 43-52. http://dx.doi.org/10.1590/S1413-294X2012000100006

Marini, J. A. S., \& Boruchovitch, E. (2014). Estratégias de aprendizagem de alunos brasileiros do ensino superior: considerações sobre adaptação, sucesso acadêmico e aprendizagem autorregulada. Revista Eletrônica de Psicologia, Educação e Saúde, 4(1), 102-126. Recuperado de https://revistaepsi.com/wp-content/uploads/artigos/2014/Ano4Volume1-Artigo5.pdf

Martins, A. A., Alves, A. F., \& Almeida, L. S. (2015). A estrutura da inteligência na infância: desenvolvimento e diferenciação cognitiva. INFAD Revista de Psicologia, 1(1), 57-66. Recuperado de http://repositorium.sdum.uminho. pt/bitstream/1822/35754/1/A\%20Estrutura\%20da\%20Intelig\%C3\%AAncia\%20na\%20Inf\%C3\%A2ncia_ Desenvolvimento\%20e\%20Diferencia\%C3\%A7\%C3\%A30\%20Cognitiva.pdf

Martins, A. A., Soares, D. L., Brito, L., Lemos, G. C., Alves A. F., \& Almeida, L. S. (2017). A diferenciação cognitiva na infância: um estudo de perfis cognitivos aos 5, 7 e 9 anos. Estudos de Psicologia (Campinas), 34(1), 87-85. http:// dx.doi.org/10.1590/1982-02752017000100009

Nielsen, T. (2014). Intellectual style theories: Different types of categorizations and their relevance for practitioners. Springer Plus, 3(737), 1-10. http://dx.doi.org/10.1186/2193-1801-3-737

Oliveira, K. L. (2008). Escala de estratégia de aprendizagem para o ensino fundamental: análise de suas propriedades psicométricas (Tese de doutorado não-publicado). Universidade Estadual de Campinas. Recuperado de http://www. bibliotecadigital.unicamp.br/document/?code=vtls000446919\&fd=y

Oliveira, K. L., Boruchovitch, E., \& Santos, A. A. A. (2010). Escala de Avaliação das estratégias de aprendizagem para o Ensino Fundamental - EAVAP-EF. São Paulo: Casa do Psicólogo.

Oliveira, K. L., Santos, A. A. A., \& Scacchetti, F. A. P. (2016). Medidas de estilos de aprendizagem para o ensino fundamental. Psicologia Escolar e Educacional, 20(1), 127-136. http://dx.doi.org/10.1590/2175-3539/2015/0201943.

Pascualon-Araujo, J. F., \& Schelini, P. W. (2013). Escala de Avaliação da Metacognição Infantil: evidências de validade e análise semântica. Avaliação Psicológica, 12(2). Recuperado de http://pepsic.bvsalud.org/scielo.php?pid=S $167704712013000200006 \&$ script=sci_arttext\&tlng=en

Prates, K. C. R., Lima, R. F., \& Ciasca, S. M. (2016). Estratégias de aprendizagem e sua relação com o desempenho escolar em crianças do ensino fundamental I. Revista Psicopedagogia, 33(100), 19-27. Recuperado de http://pepsic.bvsalud. org/pdf/psicoped/v33n100/03.pdf

Rotta, N. T., Ohlweiler. L., \& Riesgo, R. S. (2016). Transtorno de aprendizagem: abordagem neurobiológica e multidisciplinar. (2ed). Porto Alegre: Artmed. 
Simão, A. N. P., Lima, R. F., Natalin J. C., \& Ciasca, S. M. (2010). Comparação do desempenho de estudantes em instrumentos de atenção e funções executivas. Revista Psicopedagogia, 27(83), 171-80. Recuperado de http://pepsic. bvsalud.org/pdf/psicoped/v27n83/03.pdf

Sternberg, R. J. (1990). Intellectual styles: Theory and classroom implications. In B. Z. Presseisen (Eds.), Learning and thinking styles: Classroom interaction (pp.18-42). Washington: NEA.

Sternberg, R., J. (2010). Psicologia cognitiva. (5ed). Porto Alegre: Artmed.

Sternberg, R. J., Castejón, J. L., \& Bermejo, M. R. (1999). Estilo intelectual y rendimiento académico. Revista de Investigación Educativa, 17(1). Recuperado de http://revistas.um.es/rie/article/view/122261/114901.

Sternberg, R. J., Wagner, R. K., \& Zhang, L. -F. (2007). Thinking Styles Inventory: Revised II. Somerville: Tufts University.

Teixeira, A. R., \& Alliprandini, P. M. Z. (2013). Intervenção no uso de estratégias de aprendizagem diante de dificuldades de aprendizagem. Psicologia Escolar e Educacional, 17(2), 279-288. http://dx.doi.org/10.1590/S1413-85572013000200010

Valentini, F., \& Laros, J. A. (2014). Inteligência e desempenho acadêmico: revisão de literatura. Temas em Psicologia, 22(2). http://dx.doi.org/10.9788/TP2014.2-02

Veiga Simão, A. M., \& Frison, L. M. B. (2013). Autorregulação da aprendizagem: abordagens teóricas e desafios para as práticas em contextos educativos. Cadernos de Educação, 42(3). Recuperado de https://periodicos.ufpel.edu.br/ojs2/ index.php/caduc/article/view/3814/3061.

Wechsler, D. (2014). WASI: Escala Wechsler Abreviada de Inteligência. São Paulo: Casa do Psicólogo.

Xie, Q., Gao, X., \& King, R. B. (2013). Thinking styles in implicit and explicit. Learning and Individual Differences, 23, 267-271. http://dx.doi.org/10.1016/j.lindif.2012.10.014.

Zampieri, M., \& Schelini, P. W. (2013). O uso de medidas intelectuais da análise do monitoramento metacognitivo de crianças. Psicologia: Teoria e Pesquisa, 29(2), 177-193. http://dx.doi.org/10.1590/\$0102-37722013000200007

Zhang, L. F. (2015). Fostering successful intellectual styles for creativity. Asia Pacific Education Review, 16, 183-192. http:// dx.doi.org/10.1007/s12564-015-9378-5

Zhang, L., \& Sternberg, R. J. (2005). A threefold model of intellectual styles. Educational Psychology Review, 17, 1-53. http://dx.doi.org/10.1016/J.PAID.2004.11.009

Zhang, L., Sternberg, R. J., \& Fan, J. (2013). Revisiting the concept of 'style match'. British Journal of Educational Psychology, 83, 225-237. http://dx.doi.org/10.1111/bjep.12011

Zumbrunn, S. K., \& Bruning, R. (2013). Improving the writing and knowledge of emergent writers: The effects of self-regulated strategy development. Reading and Writing: An Interdisciplinary Journal, 26, 91-110. http://dx.doi. org/10.1007/s11145-012-9384-5

Received: Mach 3, 2017

Final version: September 29, 2017

Approved: October 9, 2017 